\title{
Eda U. Gerstacker Grove at the University of Michigan Methods
}

\section{Research Fellow:}

Mark Lindquist

Assistant Professor

University Of Michigan

Research Assistant:

Evan Gill

MLA Candidate

University Of Michigan

Firm Liaison:

Difei Ma, PLA

Landscape Designer

Stoss Landscape Urbanism

Firm Liaison:

Petra Geiger

Landscape Designer

Stoss Landscape Urbanism

This investigation was conducted as part of the Landscape Architecture Foundation's 2019 Case Study Investigation (CSI) program. CSI matches faculty-student research teams with design practitioners to document the benefits of exemplary high-performing landscape projects. Teams develop methods to quantify environmental, social, and economic benefits and produce Case Study Briefs for LAF's Landscape Performance Series.

Lindquist, Mark, and Evan Gill. "Eda U. Gerstacker Grove at the University of Michigan Methods." Landscape Performance Series. Landscape Architecture Foundation, 2019. https://doi.org/10.31353/cs1551

The full case study can be found at: https://landscapeperformance.org/case-studybriefs/gerstacker-grove 


\section{Benefits and Methods}

\section{Environmental Benefits}

- Reduces peak stormwater runoff rates by up to $100 \%$ for a 2-year, 24-hour storm event and up to $34 \%$ for a 100-year, 24-hour storm event.

\section{Methods}

The landscape architect calculated existing and proposed runoff rate reduction using Autodesk's Hydraflow Hydrographs Stormwater modeling software, which uses the SCS TR-20 method. The grading of the path and grass areas directs $65 \%$ of the hard surface stormwater runoff to the infiltration garden area, and $30 \%$ to underground storage via pipes, compared to its existing condition where $100 \%$ of the site drainage was via catch basins and inlets. Pre-construction impervious surfaces were 0.58 acres ( 0.05 roof, 0.53 pavement) while post-construction impervious surfaces increased to 1.10 acres ( 0.05 roof, 1.05 pavement) almost doubling the amount of impervious surfaces (Table 1). The capacity of the infiltration gardens and underground detention basin is designed to meet and exceed the University of Michigan National Pollutant Discharge Elimination System (U of M NPDES) post-construction requirements for the 2 year, 24-hour storm channel protection criteria.

\section{Calculations}

Table 1: Land use cover type, area, runoff coefficient (C) and runoff curve number (CN) preand post-construction (source: STOSS)

\begin{tabular}{|c|c|c|c|}
\hline $\begin{array}{l}\text { Pre-construction Land Use } \\
\text { Summary }\end{array}$ & & & \\
\hline Cover Type & Area $(\mathrm{AC})$ & C & $\mathrm{CN}$ \\
\hline Open space (lawn) & 3.25 & 0.35 & 78 \\
\hline Roof & 0.05 & 0.95 & 98 \\
\hline Pavement (walks) & 0.53 & 0.95 & 98 \\
\hline Totals & 3.79 & 0.45 & 81 \\
\hline $\begin{array}{l}\text { Post-construction Land Use } \\
\text { Summary }\end{array}$ & & & \\
\hline Cover Type & Area $(\mathrm{AC})$ & C & CN \\
\hline Open space (lawn) & 2.69 & 0.35 & 78 \\
\hline Rain garden/Bioretention & 0.03 & 0.2 & 49 \\
\hline Roof & 0.05 & 0.95 & 98 \\
\hline
\end{tabular}




\begin{tabular}{|l|r|r|r|}
\hline Pavement & 1.05 & 0.95 & 98 \\
\hline Total & 3.83 & 0.53 & 84 \\
\hline
\end{tabular}

Table 2: Pre- and post-construction runoff volume and peak runoff rate without BMPs (source: STOSS)

\begin{tabular}{|l|l|}
\hline Existing Runoff Volume & 11,637 CF \\
\hline Existing Peak Runoff Rate & 5.105 CFS \\
\hline Built Runoff Volume & 13,915 CF \\
\hline Built Condition Peak Runoff & 6.15 CFS \\
\hline
\end{tabular}

Table 3: Pre- and post-construction discharge [Infiltration Beds] (created from Rainfall Frequency Atlas of the United States, David M. Hershfield)

\begin{tabular}{|l|l|l|l|l|}
\hline Storm Event & $\begin{array}{l}\text { Total Pre- } \\
\text { project } \\
\text { Discharge }\end{array}$ & $\begin{array}{l}\text { Total Post- } \\
\text { project } \\
\text { Discharge }\end{array}$ & $\begin{array}{l}\text { Infiltration } \\
\text { Beds Adjusted } \\
\text { Discharge }\end{array}$ & $\begin{array}{l}\text { \% Reduction in } \\
\text { Stormwater } \\
\text { Runoff }\end{array}$ \\
\hline (year/24 hrs) & (cfs) & (cfs) & (cfs) & (\%) \\
\hline 1 & 1.8624 & 2.2992 & 0 & 100 \\
\hline 2 & 2.1728 & 2.6824 & 0 & 100 \\
\hline 5 & 2.4832 & 3.0656 & 0.3832 & 84.57 \\
\hline 10 & 2.7936 & 3.4488 & 0.7664 & 72.57 \\
\hline 25 & 3.4144 & 4.2152 & 1.5328 & 55.11 \\
\hline 50 & 3.7248 & 4.5984 & 1.916 & 48.56 \\
\hline 100 & 4.656 & 5.748 & 3.0656 & 34.16 \\
\hline
\end{tabular}

Infiltration beds are an important means of managing stormwater from the increased impervious area post-construction. Infiltration beds on the site manage an estimated $2.6824 \mathrm{cfs}$ (for a 2year, 24 hour storm). To determine the post-construction adjusted discharge rates ("Infiltration Beds Adjusted Discharge"), this number (2.6824 cfs) was subtracted from the unadjusted postconstruction rates ("Total Post-project Discharge").

Example of how "\% Reduction in Stormwater Runoff" was determined:

100-year storm event

Total Pre-project Discharge (4.656) - [Post-project] Infiltration Beds Adjusted Discharge

$(3.0656)=1.5904$

$1.5904 / 4.656=0.34=34 \%$ Reduction in Stormwater Runoff 
The infiltration gardens are an important means of managing stormwater from the increased impervious area post-construction. According to Stoss, "(the) five elective infiltration gardens will treat approximately $58 \%$ of the required volume prior to being treated again in the hydrodynamic separator. One hydrodynamic separator will treat all of the site drainage and be a Contech CDS unit or equal. Unit shall be sized to meet the removal and peak discharge flow criteria as shown on sheet c-107" (Stoss 2015, Item 6, Paragraph 2).

The exact specifications for the underground detention basin were not provided to the CSI research team by Stoss or the University in order to determine how much was being managed in the underground detention basin. Stoss does state that the basin be a Stormtech model 3500 or equal (Stoss 2015, note 3). This model, however, has a number of installation options that could drastically change the total per chamber unit storage capacity $(3.11-5.38 \mathrm{~m} 3)$ (Stormtech MC3500 information sheet).

The increased runoff volume and rate resulting from the project for a 2-year, 24-hour storm are $2,278 \mathrm{cf}$ and $1.04 \mathrm{cfs}$ respectively (from Table 2). The underground infiltration/detention basin is designed to infiltrate the volume and reduce the rate to or below existing conditions as required by the $U$ of M NPDES permit. Additionally, the basin has an overflow bypass for larger storms. The infiltration/detention basin then discharges to a 48" storm sewer that drains to the west.

\section{Sources}

Stoss Landscape Urbanism (2015) Stormwater Management Plan Summary Sheet, Drawing Number C-105

U.S. Department of Commerce, prepared by Hershfield, David M. (1961). Technical Paper No. 40, Rainfall Frequency Atlas of the United States. U.S. Government Printing Office, Washington 25, D.C. Retrieved from https://www.nws.noaa.gov/oh/hdsc/PF documents/TechnicalPaper No40.pdf

\section{https://www.stormtech.com/download files/pdf/MC3500 Information Sheet 06-19.pdf}

https://ehs.umich.edu/construction-projects/environmental-considerations/storm-watermanagement/

\section{Limitations}

Limitations of the method include the calculations being done using a model. Actual site conditions may vary. 
- Improves water quality by removing up to $80 \%$ of total suspended solids for a 2-year, 24-hour storm event.

\section{Methods}

The grading of the path and grass areas directs $65 \%$ of the hard surface stormwater runoff to the infiltration garden area, and $30 \%$ to underground storage via a hydrodynamic swirl concentrator. The hydrodynamic separator is a required BMP and is specified to treat a minimum of $80 \%$ of total suspended solids (TSS) for the volume of a 2-year, 24-hour storm. Each of the five infiltration basins is an elective BMP and has an overflow bypass for larger storms (e.g. larger than a 2 year, 24-hour event). Basins are connected to the hydrodynamic separator located under the northwest volleyball court as a required BMP. According to the landscape architect, the infiltration garden and hydrodynamic separator can remove $80 \%$ of TSS.

\section{Calculations}

Derived from materials provided by Stoss Landscape Urbanism.

\section{Sources}

Stoss Landscape Urbanism

\section{Limitations}

Limitations of the method include the calculations being done using a model. Actual site conditions may vary.

- Sequesters an estimated 1 ton of atmospheric carbon annually in 179 newlyplanted trees and approximately 1 ton of atmospheric carbon annually in 39 preserved existing trees. The tree canopies intercept an estimated 27,000 gallons of stormwater annually.

\section{Methods}

i-Tree Eco V6 is a software tool that was developed by the U.S. Forest Service to provide forestry analysis and benefits assessment (i-Tree Eco V6). Benefits from the forest level down to the individual tree can be viewed in an easily accessible format. Tree species and DBH of each tree, as well as surrounding land use, was input into i-Tree. Species and DBH were confirmed by the research team through supporting plant schedules and field observations on June 11, 2019.

Results illustrate carbon sequestration in pounds, carbon storage in pounds, and avoided runoff in cubic feet. This process was done in two separate submissions to separate preserved trees from the newly-planted trees. Benefits are expected to increase as the trees mature. These figures demonstrate the value of preserving trees as much as possible through construction, the new plantings contribute to significant future ecosystem services. 


\section{Calculations}

i-Tree has a built-in database that provides values for different tree species and sizes. At Gerstacker Grove, there were 39 trees preserved and 179 newly-planted trees, for a total of 218 trees. Annually, these 218 trees sequester 4,000 pounds or 2 tons of carbon.

The current estimate of carbon being stored by the trees is about 137 tons (24.9 tons new/ 112.4 tons existing), which is equivalent to 503 (91.4 new/ 412.2 existing) tons of CO2. The amount of carbon dioxide equivalent is found by multiplying carbon sequestration by the ratio of their atomic weights (44/12) (i-Tree Eco V6).

Newly-planted trees infiltrate about 15,089.5 gallons of water while the existing trees intercept about 11,965.8 gallons. Together the trees on the site intercept over 27,000 gallons of water annually with an estimated avoided runoff value of $\$ 248$.

$1 \mathrm{cu} \mathrm{ft}=7.48052$ gallons

$2,107.17 \mathrm{cu} \mathrm{ft}+1,599.6 \mathrm{cu} \mathrm{ft}=3706.77 \mathrm{cu} \mathrm{ft}=27,055.3$ gallons

Avoided runoff is estimated based on local weather from the nearest weather station. The total annual precipitation in 2015 was $27.1 \mathrm{in}$. The avoided runoff value is calculated based on the price of $\$ 0.067$ per cubic foot, the value achieved through savings in "gray" stormwater infrastructure (i-Tree Eco V6).

\section{Sources}

i-Tree Eco v6. Accessed June 20, 2019. https://www.itreetools.org/eco/index.php

\section{Limitations}

The i-Tree results do not take into account any shrubs or groundcover on the site.

Table 4: Preserved and newly planted vegetation

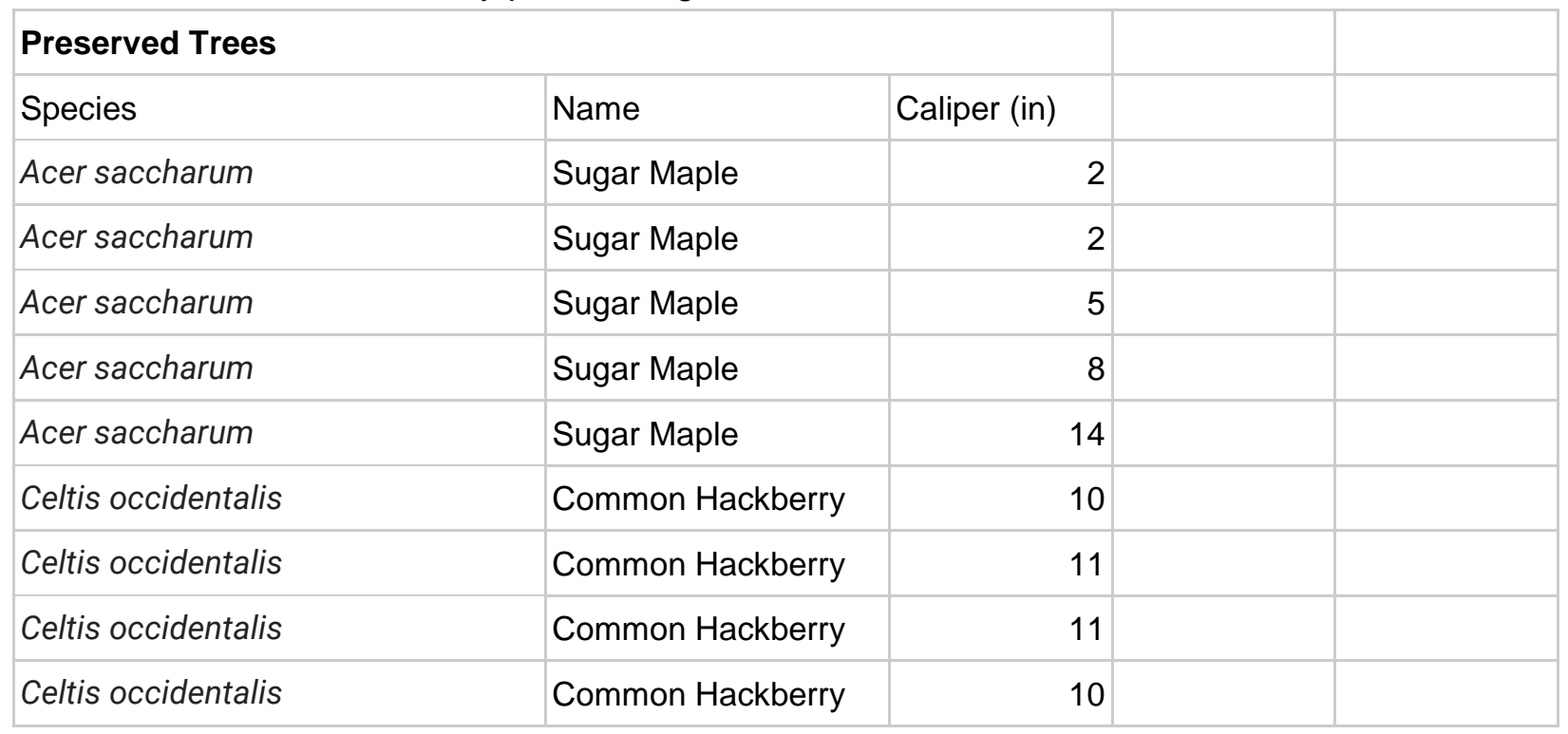




\begin{tabular}{|c|c|c|c|c|}
\hline Gleditsia triacanthos & Honey Locust & 20 & & \\
\hline Malus ioensis & Prairie Crabapple & 11 & & \\
\hline Malus ioensis & Prairie Crabapple & 8 & & \\
\hline Malus ioensis & Prairie Crabapple & 10 & & \\
\hline Malus ioensis & Prairie Crabapple & 10 & & \\
\hline Malus ioensis & Prairie Crabapple & 7 & & \\
\hline Malus ioensis & Prairie Crabapple & 8 & & \\
\hline Malus ioensis & Prairie Crabapple & 10 & & \\
\hline Malus ioensis & Prairie Crabapple & 13 & & \\
\hline Quercus macrocarpa & Bur Oak & 16 & & \\
\hline Quercus macrocarpa & Bur Oak & 13 & & \\
\hline Quercus macrocarpa & Bur Oak & 12 & & \\
\hline Tilia americana & American Linden & 10 & & \\
\hline Tilia americana & American Linden & 12 & & \\
\hline Tilia americana & American Linden & 10 & & \\
\hline Tilia americana & American Linden & 12 & & \\
\hline Tilia americana & American Linden & 15 & & \\
\hline Tilia americana & American Linden & 14 & & \\
\hline Tilia americana & American Linden & 15 & & \\
\hline Tilia americana & American Linden & 13 & & \\
\hline Tilia americana & American Linden & 13 & & \\
\hline Tilia americana & American Linden & 13 & & \\
\hline Tilia americana & American Linden & 14 & & \\
\hline Tilia americana & American Linden & 14 & & \\
\hline Tilia americana & American Linden & 13 & & \\
\hline \multirow[t]{2}{*}{ Tilia americana } & American Linden & 12 & & \\
\hline & & 391 & & \\
\hline \multicolumn{3}{|l|}{ New Trees } & Height & Count \\
\hline Acer rubrum & Red Maple & 3 & & 5 \\
\hline Acer saccharum "Autumn Flame" & Sugar Maple & 3 & & 4 \\
\hline Acer saccharum "Green Mountain" & Sugar Maple & 3 & & 4 \\
\hline
\end{tabular}




\begin{tabular}{|l|l|r|r|}
\hline Amelanchier arborea & Serviceberry & 3 & 71 \\
\hline Carya cordiformis & Bitternut Hickory & 3 & 1 \\
\hline Carya ovata & Shagbark Hickory & 3 & 1 \\
\hline Fagus grandifolia & American Beech & 3 & 10 \\
\hline Gymnocladus dioicus & Kentucky Coffee Tree & 3 & 2 \\
\hline Juglans cinerea & American Butternut & 3 & 1 \\
\hline Liriodendron tulipifera & Tulip Poplar & 3 & 5 \\
\hline Nyssa sylvatica & Black Gum & 3 & 3 \\
\hline Platanus occidentalis & American Sycamore & 3 & 5 \\
\hline Quercus alba & White Oak & 3 & 3 \\
\hline Quercus acutissima & Sawtooth Oak & 3 & 2 \\
\hline Quercus imbricaria & Shingle Oak & 3 & 2 \\
\hline Quercus macrocarpa & Bur Oak & 3 & 4 \\
\hline Quercus rubra & Red Oak & 3 & 6 \\
\hline Quercus velutina & Black Oak & & $10-11$ \\
\hline Taxodium distichum & Bald Cypress & & 44 \\
\hline & & & \\
\hline
\end{tabular}

\section{Social Benefits}

- Accommodates significant foot and bike traffic even outside of the standard school year. An average of over $\mathbf{4 3 0}$ visitors per hour, primarily students, were observed using the space on three weekdays in the summer.

\section{Methods}

A people moving count developed by the Gehl Institute was used to assess site user numbers and activities. A sample of site users was conducted on Thursday June 27th, Monday July 1st, and Monday July 8th during the summer of 2019. The People Moving Count was performed three times by three individuals in three locations within the site for 15 minutes per session. The Count These numbers were then transcribed into a spreadsheet where post-processing analysis was performed. 


\section{Calculations}

\begin{tabular}{|c|c|c|c|c|}
\hline & Roof & Duderstadt & Middle & \\
\hline & Walking & Walking & Walking & \multirow[t]{4}{*}{ Total of averages } \\
\hline $\begin{array}{r}6 / 27 \\
15 \mathrm{~min}\end{array}$ & 45 & 145 & 95 & \\
\hline $\begin{array}{r}7 / 1 \\
15 \mathrm{~min}\end{array}$ & 41 & 215 & 127 & \\
\hline $\begin{array}{r}7 / 8 \\
15 \mathrm{~min}\end{array}$ & 47 & 131 & 127 & \\
\hline \multirow[t]{5}{*}{ Average } & 44.3 & 163.6 & 116.3 & 324.3 \\
\hline & Bicycles & Bicycles & Bicycles & \multirow[t]{4}{*}{ Total of averages } \\
\hline & 1 & 2 & 1 & \\
\hline & 1 & 1 & 1 & \\
\hline & 1 & 2 & 1 & \\
\hline Average & 1 & 1.6 & 1 & 3.6 \\
\hline
\end{tabular}

Total of averages for all 3 observation locations per 15 minutes (walking) $=324.3$ / 3 (average of total) 108.1 (per 15 minute period) $\times 4=432.4$ average per hour over the entire site

Total of averages for all 3 observation locations per 15 minutes (bicycles) $=3.6$ / 3 (average of total) 1.2 (per 15 minute period) $\times 4=4.8$ average per hour over the entire site

432.4 (walking) +4.8 (bicycles) $=\mathbf{4 3 7 . 2}$ average per hour

\section{Sources}

CSI research team observations in the field using Gehl Institute observation methods.

Gehl Institute. People Moving Count. https://gehlinstitute.org/tool/people-moving-count/

\section{Limitations}

These numbers are taken as a snapshot in a point in time, and as such are an estimate of space use. These observations were done on weekdays in the summer when student foot traffic is minimal and actual use during term-time could vary widely. As the results of an observational method, the counts are subject to human error. 
- Creates a safe environment with to $98 \%$ of $\mathbf{5 2}$ surveyed users reporting that they feel safe or very safe on-site.

- Provides a community and civic/ceremonial space. Of surveyed users, $78 \%$ felt it performs well as a civic/ceremonial space and $78 \%$ said it performs well at being a neighborhood space for playing, relaxing, and being social.

\section{Methods}

A survey was developed (guided by the Participant Survey Worksheet created by the Gehl Institute) to assess site user behavior and experience and deployed via Qualtrics. A convenience sample of site users were selected via intercept sampling which was conducted on Thursday June 27th, Monday July 1st, and Monday July 8th during the summer of 2019 from 9 am to $5 \mathrm{pm}$. Respondents completed a digital survey on an iPad to assess their perceptions of the site based on 39 questions (Appendix A), which also included demographic questions. Results from respondents ( $\mathrm{N}=60$ ) were summarized (Qualtrics and SPSS).

\section{Sources}

Survey Questions (see Appendix A)

Gehl Institute. Participant Survey Worksheet. https://gehlinstitute.org/tool/participant-survey/

\section{Calculations}

The data was collected using Qualtrics online survey platform and analyzed with SPSS.

- $98 \%$ of respondents ( $\mathrm{N}=52)$ feel "safe" or "very safe" in Gerstacker Grove.

- $78 \%$ of respondents ( $\mathrm{N}=52$ ) feel that Gerstacker Grove performs well or very well at being a neighborhood space (with space to play, relax, or be social).

\section{Limitations}

Due to the timeline of this case study and the necessity of IRB review, the survey was administered in the summer semester. The sample size was limited due to the number of hours the research team could spend in the field. Additional respondents would improve the reliability of the statistical results.

Notable results of the survey regarding ways in which the landscape contributes to the academic and social value of the site are as follows:

- $93 \%$ of respondents $(\mathrm{N}=52)$ feel strongly positive or somewhat positive about the North Campus at the University of Michigan

- $93 \%$ of respondents $(\mathrm{N}=52)$ feel strongly positive or somewhat positive about Gerstacker Grove. 
- $79 \%$ of respondents $(\mathrm{N}=41)$ feel that Gerstacker Grove performs as a civic/ceremonial space very well.

- $53 \%$ of respondents ( $\mathrm{N}=32$ ) felt proud of Gerstacker Grove

- The top three words to describe Gerstacker Grove are: open (frequency=19), green (frequency=13), and beautiful (frequency=9).

\section{Economic Benefits}

- Saves an estimated 12 labor hours, 13.2 gallons of fuel, and $144 \mathrm{lbs}$ of fertilizer each year resulting in a total estimated savings of $\$ 410$ as compared to turf within the infiltration beds and no-mow grass areas.

\section{Methods}

A number of sources were used to find the time and cost associated with the maintenance of turf based on industry standards. This cost was broken down to according to the reduction in turf area and cost savings were reverse-engineered from these numbers.

\section{Calculations}

- Lawn Mowing

- Lawn maintenance crew average pay: $\$ 44,000$ salary ( $\$ 22 /$ Hour)

- Area of beds (25,480 sf),

- 28 weeks of mowing (standard for Ann Arbor, Ml)

- Total time to mow one acre (20 min with 60 " bed mower)

- 17 Minutes saved per week (8 hours a year)

- Eight hours multiplied by 22 dollars an hour $=\$ \mathbf{1 7 6}$

- Fuel

- 28 weeks of Mowing

- Total time to mow one acre (20 min with 60 " bed mower)

- 17 Minutes saved per week (8 hours a year)

- 1 gallon of fuel per hour

- \$3.16 price per gallon for diesel

- 8 hours of motor running multiplied by $\$ 3.16$ price of diesel $=\$ \mathbf{2 5 . 2 8}$

- Fertilizer

- Area of beds $(25,480 \mathrm{sqft})$ removed from the total turf area

- 36lbs of fertilizer per application (144lbs a year)

- $\$ 40$ for $50 \mathrm{lbs}$ multiplied by $144 \mathrm{lbs}=\$ \mathbf{1 2 0}$

- Other Maintenance

- Reduction in mower use time

- Aerating the turf

- Estimated 4 additional hours added to labor reduction $=\$ 88$

\section{Sources:}


https://extension.illinois.edu/lawnfaqs/fertilizing.cfm

https://www.grasshoppermower.com/fuel-calculator/\#stage 2

https://www. siteone.com/

\section{Limitations}

The University of Michigan Facilities and Operations were not able to provide specific information requested on maintenance. As a result, calculations are based on industry standards and were completed by the research team. 


\section{Appendix A: Qualtrics Survey}

LAF Outdoor Space Evaluation

\section{Consent Letter}

Dear outdoor space user:

Your input on this outdoor space is important to research we are conducting. I am a graduate student under the direction of Dr. Mark Lindquist in the School for Environment and Sustainability at The University of Michigan. I invite you to participate in a research study that is being conducted under the auspices of the Landscape Architecture Foundation to understand your perception of this space. You must be 18 years of age or older to participate. Your participation will involve taking a questionnaire that may take about 10 minutes. Your involvement in the study is voluntary, and you may choose not to participate or to stop at any time without penalty or loss of benefits to which you are otherwise entitled. If you decided to stop or withdraw from the study, the information/data collected from or about you up to the point of your withdrawal will be kept as part of the study and may continue to be analyzed. Your data is confidential and only researchers will have access to data stored on password-protected devices. The results of the research study may be published, buy your name or any identifying information will not be used. In fact, the published results will be presented in summary form only.

The Findings from this project may provide information on how you and others perceive this space. There are no known risks or discomforts associated with this research. At the end of the survey, you will be given the opportunity to be entered into a drawing for a $\$ 25$ gift card for your participation.

If you have questions about this research project, please feel free to contact me at evgill@umich.edu.

By checking the box below, you are agreeing to participate in the above-described research project.

Thank you for your consideration and for providing your insight on this outdoor space. Please keep this letter for your records.

Sincerely,

Evan Gill and Mark Lindquist 
Agree and continue

Disagree

\section{Start of Block: Demographics}

What is your age?

o 18-24

O $\quad 25-34$

० $\quad 35-44$

○ $\quad 45-54$

0 $55-64$

० $65-74$

0 $75+$

What is the highest level of education you have completed?

$0 \quad$ Less than 9th grade

- Some High School

- $\quad$ Completed High School (through grade 12)

- Some college, no degree

- Bachelor's or Associate's Degree

- Graduate or Professional Degree

Do you identify as

o Male

- Female

- Gender nonconforming

- None of the above

o Prefer not to say

Do you identify as (one or more boxes)

American Indian or Alaska Native

Asian, including the Indian subcontinent

Black or African American

Hispanic / Latino / Spanish origin

Native Hawaiian or other Pacific Islander

White

None of the above

Prefer not to say 
In which country have you spent the majority of your life?

$\nabla$ Afghanistan ... Zimbabwe

Are you currently employed?

o Yes

O No

What is your job?

Are you currently a student?

o Yes

o No

What is the address of your current residence? (This will only be used for determining service area of the plaza)

\section{End of Block: Demographics}

\section{Start of Block: Frequency and Duration of Visits}

How often do you visit this place?

o Daily

o Weekly

o $\quad$ Every few months

- Rarely (once per year or less)

o First time here

How did you get here today? (Select option traveled for longest distance)

$\begin{array}{ll}0 & \text { Walk } \\ 0 & \text { Bike } \\ 0 & \text { Bus } \\ 0 & \text { Private Car } \\ 0 & \text { Taxi/Rideshare }\end{array}$


0

Other

What brings you to this space today? (Main reason)

o Just passing through

o School

o Work

o $\quad$ Spending time with my family

o Meeting up with friends

o Spending time by myself

o Sightseeing

o Recreation/Sports/Exercise

o Walking my pet

- Cultural event/Performance

o Political Event/Protest

Are you headed anywhere in particular?

o Home

o Work

o School

o Cultural institution

- Restaurant/Bar

- Store

- Another public space

o Other

How much time do you plan on spending here today?

o Less than $10 \mathrm{~min}$.

o $10 \mathrm{~min}$.

o $20 \mathrm{~min}$.

o $30 \mathrm{~min}$.

o $45 \mathrm{~min}$.

o 1 hour or more

\section{End of Block: Frequency and Duration of Visits}

\section{Start of Block: Sentiment}

What best describes your relationship to Gerstacker Grove? (check all that apply) Neighbor/Resident

Employee (of nearby institution/business) 
$\square \quad$ Student (of nearby school)

$\square \quad$ Tourist Attendee (cultural event or institution)

Other. Please describe

How do you feel about North Campus at The University of Michigan?

- Strongly positive

- Somewhat positive

o Neutral

o Somewhat negative

- Strongly negative

How do you feel about this particular public space?

- Strongly positive

o Somewhat positive

o Neutral

- Somewhat negative

o Strongly negative

What three words would you use to describe this public space?

o First

o Second

o Third

What two things would you like to do in the public spaces of this area that you can't do now?

o First

o Second

List some things you wish were here but aren't:

How do you feel this public space performs as a civic/ceremonial space?

o Very well

o Somewhat well

o Neutral

- Somewhat poorly

o Very poorly

o Don't know 
How do you feel the public spaces of this area perform as neighborhood spaces? (for example, as places to play, relax, be social)

o Very well

o Somewhat well

o Neutral

- Somewhat poorly

o Very poorly

o Don't know

How would you rate your feelings of safety in this space right now?

o Very safe

o Somewhat safe

o Neutral

- Somewhat unsafe

o Very unsafe

o Don't know

What would make you feel safer in this space?

$\begin{array}{ll}\text { “I am proud of Gerstacker Grove” } \\ \text { o } & \text { Strongly Disagree } \\ 0 & \text { Disagree } \\ 0 & \text { Neutral } \\ 0 & \text { Agree } \\ 0 & \text { Strongly Agree } \\ 0 & \text { Don't know }\end{array}$

What is your favorite place in Gerstacker Grove?

What is your favorite part of Gerstacker Grove?

\section{End of Block: Sentiment}

\section{Start of Block: Seasonality}


Do you spend time outdoors in the winter?

- No, I don't spend much time outdoors in the winter

o I spend limited time outdoors in the winter

$0 \quad$ Only if the weather is nice

$0 \quad$ Yes, I spend time outdoors in the winter, rain or shine

You spend time outdoors in winter, Where do you go? (select all that apply)

I leave the city

I mostly leave the city, but occasionally go Downtown

I spend time in the city, but rarely/never Downtown

I spend time Downtown

If you spend time outdoors in winter, What do you do? (select all that apply)

I spend time commuting to and from work, school, etc.

I spend time shopping/errands

My occupation requires me to be outdoors

I meet up with friends/family

I sit outside enjoying food and drink

I enjoy my garden/terrace

I walk my pet

I take my children to the playground

I spend time engaging in recreational activities

Other. please describe

What would encourage you to spend more time outdoors this winter? (select all that apply)

More shelter from the snow/rain/wind

More seating, protected from snow/rain/wind

Heated outdoor serving areas, food and drinks

More/improved lighting

More activities on sunny days

More activities on snowy/rainy/cold days

More events/activities, such as

Other. Please describe

\section{End of Block: Seasonality}

\section{Start of Block: Social Mixing}


Please take a few moments to look at the people here. Do you recognize anyone you weren't already planning to meet?

o No, I don't recognize anyone here right now.

o Yes, I recognize a familiar face, but I don't 'know' them

$0 \quad$ Yes, I recognize someone I know but didn't plan to meet

Did you interact with someone here today who you did NOT come with?

o Yes, I have interacted with people

o No

Did you know them before today?

o Yes, my friend

$0 \quad$ Yes, a friend of a friend

$0 \quad$ No, but I recognized them from somewhere

o No, I have never seen them before

What brought about your interaction? (select all that apply)

I knew the person

Pets

Children

An activity. Please describe

Volunteering

Sat next to each other

Other. Please describe

\section{End of Block: Social Mixing}

\section{Start of Block: Green Infrastructure}

Do you know, or believe you know, what Green Infrastructure is?

o Yes

- Maybe

o No 